\title{
Ethanol, Acetaldehyde, and
}

\section{Myocardial Protein Synthesis}

\author{
Sidney S. Schreiber, Kay Brmen, Murray Oratz, and \\ Marcus A. RothschiLd \\ From the Department of Nuclear Medicine, New York Veterans Hospital, and \\ the Department of Medicine, New York University School of Medicine, \\ New York 10010
}

\begin{abstract}
A B S TRACT The cause of alcoholic myocardiopathy is unknown. The effects of acute exposure to ethanol or its metabolite acetaldehyde on protein synthesis in working, intact, guinea pig hearts in vitro were studied utilizing lysine ${ }^{-14} \mathrm{C}$ perfusion. Ethanol at $250 \mathrm{mg} / 100 \mathrm{ml}$, a level sufficient to markedly inhibit hepatic production of albumin, did not alter cardiac function, the equilibration of the intracellular free lysine pool in either ventricle, or the incorporation of lysine $-{ }^{14} \mathrm{C}$ into protein. Thus, in controls and ethanol-perfused hearts, the incorporation of lysine in $3 \mathrm{hr}$ was $44.1 \pm 1.5$ and $42.8 \pm 1.2 \mu$ moles lysine/g protein $\mathrm{N}$ for the right ventricles and $25.6 \pm 1.0$ and $24.3 \pm 0.8$ for the left ventricles, respectively. Only at lethal levels, $1500 \mathrm{mg} / 100 \mathrm{ml}$ ethanol, was protein synthesis depressed. Acetaldehyde $3.5 \mathrm{mg} / 100 \mathrm{ml}(0.8 \mathrm{~mm})$ effected a markedly positive chronotropic and inotropic effect on the perfused heart and slightly depressed equilibration of the intracellular free lysine pool. However, determinations of protein incorporation of lysine ${ }^{14} \mathrm{C}$ based on intracellular lysine- ${ }^{14} \mathrm{C}$ specific activities showed a significant decrease from control right and left ventricle values, to $27.1 \pm 2.8$ and $14.9 \pm 1.9$. Propanalol, which abolished the chronotropic effect, did not prevent the inhibition of protein synthesis. The studies suggest that acetaldehyde, which inhibits cardiac protein synthesis in vitro, may play a role in alcoholic myocardiopathy by interfering with normal myocardial protein synthesis.
\end{abstract}

\section{INTRODUCTION}

The occurrence of cardiomyopathy in chronic alcoholics is well known, but the causes are as yet unclear (1). Metabolic effects of ethanol, such as accumulation of

Received for publication 28 February 1972 and in revised form 11 July 1972. triglycerides despite a decrease in fatty acid extraction $(2,3)$, have been suggested as a cause of ultimate impairment of myofibrillar function. The suggestion has also been made that the detrimental effects of ethanol may actually be an acetaldehyde effect, mediated through the release of norepinephrine causing chronic chronotropic and inotropic effects which may often play a role in the development of the myopathy (4).

It has been reported that acute exposure to alcohol decreases the capacity of the liver to synthesize albumin to one-third that of the control (5). In view of the rapid inhibitory effect, it was felt to be of interest to study the effect of alcohol in the perfused heart to see if myocardial protein synthesis was similarly inhibited. In addition ,since alcohol is apparently not metabolized by the heart $(6,7)$, the effect of a primary metabolite, acetaldehyde (4), synthesized in liver was also studied.

The results indicated that acute exposure to levels of alcohol that decreased albumin synthesis in the perfused liver had no effect on protein synthesis in the perfused heart. However, acetaldehyde, at levels that produce a marked chronotropic and inotropic effect, markedly inhibited protein synthesis of total cardiac protein.

\section{METHODS}

Protein synthesis was determined in vitro by perfusing isolated hearts with lysine $-{ }^{14} \mathrm{C}$ in an amino acid-fortified Krebs-Henseleit solution for $3 \mathrm{hr}$. Perfusion was carried out under control conditions and in the presence of ethanol or acetaldehyde in the perfusate.

Operative preparation. Young guinea pigs, weighing 250 $300 \mathrm{~g}$, were used in this study. The animals were fed a standard laboratory diet ad lib. The operative preparation for perfusion was slightly modified from that previously described (8). After Nembutal anesthesia, the descending aorta was cannulated. Perfusion with Krebs-Henseleit solution directed toward the heart was begun immediately and the pulmonary artery opened. Blanching of the myocardium and coronary circulation was noted almost immediately. In 


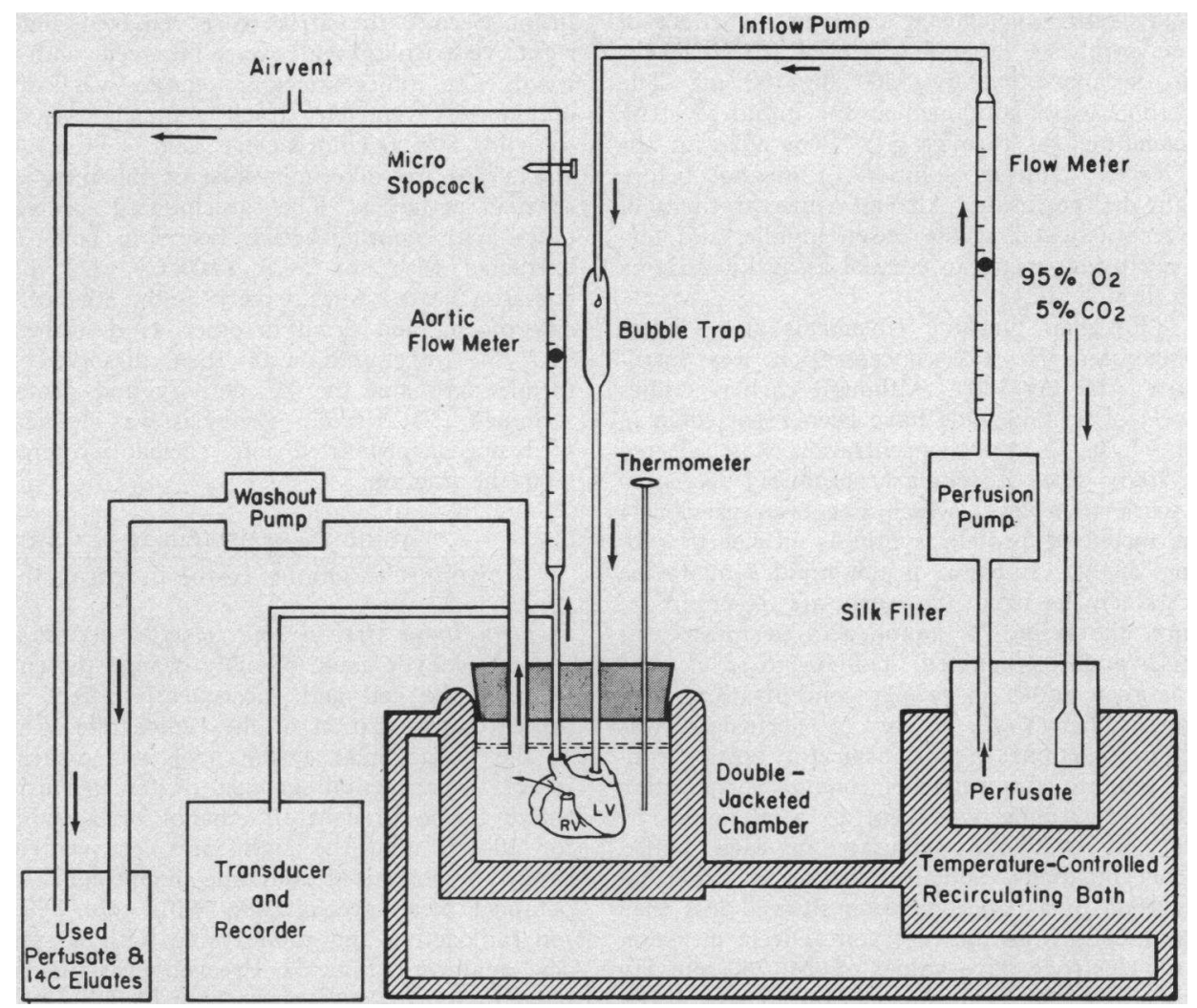

FIgURE 1 Apparatus for measurement of incorporation of lysine- ${ }^{14} \mathrm{C}$ into protein in the perfused guinea pig heart. See Methods.

order to bypass the aortic arch branches, a new cannula was then secured in the ascending aorta with the cannula directed toward the heart and the tip of the cannula placed distally to the aortic valve. Perfusion was rapidly transferred to this new cannula in order to maintain the coronary flow. After hilar ligation, both lungs were removed, and a second cannula passed through the left auricular appendage and mitral valve into the left ventricle. This latter cannula was secured by a ligature about the AV ring with care taken not to embarrass the circumflex coronary artery at the AV junction. The perfusion fluid was next transferred to this second cannula, since in this system, perfusate is presented to the left ventricle which then pumps it out the aorta. The perfusion flow was $45-50 \mathrm{ml} / \mathrm{min}$ per $\mathrm{g}$ dry weight $(7-8 \mathrm{ml} / \mathrm{min}$ in these hearts $)$.

Perfusion system. The heart with its two cannulae was transferred to a double-jacketed perfusion chamber (capacity $150-200 \mathrm{ml}$ ) with temperature maintained in the chamber by circulating fluid through the outer jacket (Fig. 1). Perfusion with amino acid-fortified Krebs-Henseleit solution containing lysine $-{ }^{14} \mathrm{C}$ with or without the test drugs was begun. The two cardiac cannulae were connected by No. 18 stainless steel needles passed through the chamber cover to the left ventricular inflow perfusion and to aortic outflow. The fluid pumped out by the left ventricle that did not enter the coronary circulation passed through an aortic outflow meter to a waste container and was not recirculated. The coronary circulation emptied through the right heart and opened pulmonary artery into the perfusion chamber fluid, which was kept at a level sufficient only to cover the heart by an aspirating peristaltic pump. The aspirated fluid was also carried to the waste-collecting container and not recirculated. Thus, any metabolite or enzyme possibly released from the heart was not recirculated.

In this model, aortic and hence coronary artery pressure was maintained at a mean of $40 \mathrm{~mm} \mathrm{Hg}$ by partially closing the exit of the aortic flow meter with a microvalve. In the perfused young guinea pig heart, this level of pressure has been found sufficient to allow adequate perfusion without contractile failure for periods longer than $4 \mathrm{hr}$ (8). This level was used as the control pressure for the study. Since protein synthesis has been found to be sensitive to elevations of aortic pressure in this perfusion system (9), the experiments with alcohol and acetaldehyde were also carried out with the aortic pressures maintained at the control levels. Perfusion flow and aortic outflow were accurately measured by the flow meters, and coronary flow was calculated as the difference between the two. Aortic pressures and heart rates were monitored by a pressure transducer connected to the aortic outflow by a $\mathrm{T}$ tube, and recordings were made at 5- to 10 -min intervals through out all the experiments.

Perfusate. The perfusate was an amino acid-fortified Krebs-Henseleit solution used previously in this model (9), oxygenated with $95 \% \quad \mathrm{O}_{2}-5 \% \quad \mathrm{CO}_{2}$ maintained at $37^{\circ} \mathrm{C}$ and at a $\mathrm{pH}$ of 7.45 , and containing uniformly labeled L-lysine${ }^{14} \mathrm{C}$ (SA 100,000-150,000 cpm/ $\mu$ mole, New England Nuclear Corp. (Boston, Mass.), greater than $98 \%$ purity as $\mathrm{I}$.-lysine 
by chromatography). In experiments studying the effect of ethanol on protein synthesis, ethanol was used at two levels, $250 \mathrm{mg} / 100 \mathrm{ml}$ or approximately $1500 \mathrm{mg} / 100 \mathrm{ml}$. The alcohol concentration was maintained at the initial level by passing the oxygenating gas through a 3\% (or 30\% for the higher ethanol levels) aqueous solution of alcohol before bubbling through the perfusate. Alcohol concentrations of the perfusates were assessed at the onset, middle, and termination of the perfusions using an ethanol assay kit (Sigma Chemical Co., St. Louis, Mo.).

Acetaldehyde (Eastman Organic Chemicals Div., Eastman Kodak, Rochester, N. Y.) concentration was maintained at $0.8 \mathrm{~mm}(3.5 \mathrm{mg} / 100)$. Although earlier studies using higher levels of acetaldehyde have been reported in in vitro perfusions $(4,6,7)$, this concentration was selected for the present study since it regularly produced increased amplitude and work to a level which has been previously shown to effect increased protein synthesis in hearts subjected to loading $(8,9)$. In view of the rapid evaporation and loss of acetaldehyde from the perfusate reservoir at room temperature, the lysine- ${ }^{14} \mathrm{C}$ amino acid perfusate was initially prepared and oxygenated, chilled to $2^{\circ} \mathrm{C}$, and acetaldehyde was then added in proper concentration. 1500 $\mathrm{ml}$ of perfusate, sufficient for $3 \mathrm{hr}$ of perfusion, was divided into $750-\mathrm{ml}$ portions in two aspirator bottles connected by a $\mathrm{Y}$ tube to the perfusion pump. Evaporation during subsequent rewarming was kept to a minimum by layering mineral oil over the perfusate in each bottle. Acetaldehyde concentrations actually measured (10) at onset and termination of a $3 \mathrm{hr}$ perfusion showed less than $5 \%$ loss of acetaldehyde from the reservoir. Direct measurements with an $\mathrm{O}_{2}$ electrode gave values of $690-700 \mathrm{~mm} \mathrm{Hg}$ $\mathrm{O}_{2}$ tension throughout the perfusion period. These levels were identical with the control $\mathrm{O}_{2}$ tension. In addition the perfusate $\mathrm{pH}$, an index of the $\mathrm{CO}_{2}$ tension, remained constant.

Determination of protein synthesis in the perfused heart. Protein synthesis was measured by determining the incorporation of lysine ${ }^{14} \mathrm{C}$ into isolated and purified total protein from both right and left ventricles. After the per- fusion period, the atria were removed and discarded. The right ventricular wall was removed and separately analyzed. The interventricular septum was considered as part of the left ventricle. Each ventricle was homogenized in ice-cold 5\% trichloroacetic acid (TCA). The supernate was saved for determinations of the intracellular lysine $-{ }^{14} \mathrm{C}$ specific activities. The precipitated protein was washed twice with nonradioactive lysine in cold TCA, the RNA extracted with hot TCA $\left(100^{\circ} \mathrm{C}\right)$, and the resultant precipitate treated successively with ethanol, ethanol: ether: chloroform, and dried in ether as described previously (8, 9 ). The precipitate was then dissolved in concentrated formic acid and the ${ }^{14} \mathrm{C}$ activity and protein nitrogen determined (9). Protein synthesis was defined as micromoles of lysine incorporated into cardiac protein and calculated from the fraction:

\section{lysine ${ }^{-14} \mathrm{C} / \mathrm{g}$ protein $\mathrm{N}$ of ventricle lysine $-{ }^{14} \mathrm{C} / \mu$ moles lysine in intracellular pool}

Intracellular free lysine specific activity. Since alcohol or acetaldehyde could possibly change the entrance of lysine${ }^{14} \mathrm{C}$ into the cell and subsequently affect measurements of protein incorporation of the radioactive lysine, equilibration of the intracellular lysine pool was measured in the different experimental groups. After perfusion with radioactive lysine in control, ethanol or acetaldehyde perfusate for 10-180 $\mathrm{min}$, the right and left ventricles were separately homogenized and the nonprotein supernatant fluid obtained after precipitation with cold $5 \%$ TCA analyzed for radioactive and total lysine with a split stream amino acid analyzer (Phoenix Precision Instrument Co., Philadelphia, Pa.) (analyses carried out by Dr. Louis Fishman, Department Biochemistry New York University School of Dentistry). In most studies, the intracellular lysine specific activity was corrected by the extracellular lysine activity and content determined from the inulin- ${ }^{10} \mathrm{C}$ space separately determined $(32 \%)$. This value for extracellular space is similar to that found by Morgan et al. with sorbitol (11) in the perfused rat heart. In some of the studies, after

TABLE I

Ethanol and Acetaldehyde Effect on the Perfused Guinea Pig Heart

\begin{tabular}{|c|c|c|c|c|c|}
\hline Experimental group & $\begin{array}{c}\text { Aortic } \\
\text { systolic P }\end{array}$ & $\begin{array}{l}\text { Amplitude of } \\
\text { contraction }\end{array}$ & Heart rate & $\begin{array}{l}\text { Coronary } \\
\text { flow }\end{array}$ & $\mathbf{S P} \times \mathbf{R}^{*}$ \\
\hline & $m m H_{g}$ & $m m \mathrm{Hg}$ & beats $/ \min$ & $m b / \min$ & \\
\hline $\begin{array}{l}\text { Control (13) } \\
\text { Ethanol (12) }\end{array}$ & $40.0 \pm 1.3$ & $10.0 \pm 0.3$ & $184 \pm 6$ & $3.9 \pm 0.3$ & $7000 \pm 400$ \\
\hline $\begin{array}{c}250 \mathrm{mg} / 100 \mathrm{ml} \\
\text { Significance }\end{array}$ & $\begin{array}{l}40.0 \pm 1.1 \\
\mathrm{NS}\end{array}$ & $\begin{array}{l}10.0 \pm 0.3 \\
\text { NS }\end{array}$ & $\begin{array}{c}183 \pm 8 \\
\mathrm{NS}\end{array}$ & $\begin{array}{c}3.4 \pm 0.3 \\
\text { NS }\end{array}$ & $\begin{array}{c}7100 \pm 450 \\
\text { NS }\end{array}$ \\
\hline \multicolumn{6}{|l|}{ Ethanol (10) } \\
\hline $1300-1700 \mathrm{mg} / 100 \mathrm{ml}$ & $40.7 \pm 1.6$ & $9.0 \pm 0.4$ & $\begin{array}{l}156 \pm 12 \\
P<0.1\end{array}$ & $\begin{array}{l}4.9 \pm 0.5 \\
P<0.2\end{array}$ & $6350 \pm 450$ \\
\hline Significance & NS & NS & NS & NS & NS \\
\hline \multicolumn{6}{|l|}{ Acetaldehyde (6) } \\
\hline $\begin{array}{l}0.8 \mathrm{~mm} \\
\text { Significance }\end{array}$ & $\begin{array}{l}41.2 \pm 0.8 \\
\mathrm{NS}\end{array}$ & $\begin{array}{l}17.2 \pm 0.2 \\
P<0.001\end{array}$ & $\begin{array}{c}213 \pm 12 \\
P<0.05\end{array}$ & $\begin{array}{l}5.3 \pm 0.5 \\
P<0.05\end{array}$ & $\begin{array}{l}8773 \pm 560 \\
P<0.02\end{array}$ \\
\hline
\end{tabular}

Values given for each group are the mean values of 5 - to 10 -min readings during the experiment.

Significance and $P$ values are related to control group.

* SP $\times \mathrm{R}$, approximation of work = peak systolic pressure $\mathrm{X}$ rate (13). 
TABLE II

Protein Synthesis with Ethanol and Acetaldehyde after $3 \mathrm{Hr}$ of Perfusion

\begin{tabular}{|c|c|c|c|c|c|c|}
\hline \multirow[b]{3}{*}{ Experiment } & \multicolumn{4}{|c|}{ Lysine $-{ }^{14} \mathrm{C}$ incorporated into protein } & \multicolumn{2}{|c|}{ Protein $\mathrm{N} / 100 \mathrm{~g}$ ventricle } \\
\hline & A & B & C & $\mathrm{D}$ & $\mathrm{E}$ & F \\
\hline & RV & LV & RV & LV & RV & LV \\
\hline \multicolumn{7}{|c|}{ mmoles lysine $/ g$ protein $N$} \\
\hline Control (13) & $28.6 \pm 1.0$ & $16.6 \pm 0.7$ & $44.1 \pm 1.5$ & $25.6 \pm 1.0$ & $1.33 \pm 0.05$ & $1.51 \pm 0.04$ \\
\hline Ethanol (12) & $27.7 \pm 0.8$ & $15.8 \pm 0.5$ & $42.8 \pm 1.2$ & $24.3 \pm 0.8$ & $1.31 \pm 0.06$ & $1.52 \pm 0.04$ \\
\hline $250 \mathrm{mg} / 100 \mathrm{ml}$ & NS & NS & NS & NS & NS & NS \\
\hline Ethanol (10) & $17.0 \pm 1.7$ & $13.4 \pm 0.9$ & $26.2 \pm 2.6$ & $20.5 \pm 1.4$ & $1.20 \pm 0.03$ & $1.46 \pm 0.05$ \\
\hline $1300-1700 \mathrm{mg} / 100 \mathrm{ml}$ & $P<0.001$ & $P<0.05$ & $P<0.001$ & $P<0.05$ & $P<0.05$ & NS \\
\hline Acetaldehyde (6) & $16.0 \pm 1.8$ & $8.8 \pm 1.2$ & $27.1 \pm 2.8$ & $14.9 \pm 1.9$ & $1.28 \pm 0.05$ & $1.50 \pm 0.05$ \\
\hline $0.8 \mathrm{~mm}$ & $P<0.001$ & $P<0.001$ & $P<0.001$ & $P<0.001$ & NS & NS \\
\hline Acetaldehyde (3) & $16.1 \pm 1.3$ & $10.0 \pm 1.8$ & $24.7 \pm 2.0$ & $15.3 \pm 2.7$ & $1.30 \pm 0.03$ & $1.51 \pm 0.05$ \\
\hline + Propanalol & $P<0.001$ & $P<0.001$ & $P<0.001$ & $P<0.001$ & NS & NS \\
\hline
\end{tabular}

Columns A and B, incorporation of lysine calculated from: $\frac{\text { lysine- }{ }^{14} \mathrm{C} \text { incorporated into protein } / \mathrm{g} \text { protein } \mathrm{N}}{\text { Perfusate lysine- }{ }^{14} \mathrm{C} \text { specific activity }}$

Columns $\mathrm{C}$ and $\mathrm{D}$, incorporation of lysine calculated from : $\frac{\text { lysine- }{ }^{14} \mathrm{C} \text { incorporated into protein/g protein } \mathrm{N}}{\text { Intracellular free lysine pool specific activity }}$

Numbers in parenthesis indicate number of separate studies.

$P$ values compares significance of studies with the control group.

completion of perfusion, the hearts were washed with $30 \mathrm{ml}$ of amino acid-free Krebs-Henseleit solution which rapidly removes small extracellular molecules (12), and the intracellular specific activities determined from the non-TCA precipitable fraction. Specific activities of lysine- ${ }^{14} \mathrm{C}$ by either method were not statistically different, and the data were therefore pooled. Since equilibration studies were done on different days with perfusates of varied specific activities, the intracellular lysine $-{ }^{14} \mathrm{C}$ specific activities were expressed as a fraction of the extracellular specific activity, i.e., the specific activity of the perfusate. Thus, with full equilibration of the intracellular lysine pool, the fraction would be 1.0. Pool size was also determined and expressed as micromoles/g left ventricle or right ventricle wet weight.

\section{RESULTS}

Ethanol $(250 \mathrm{mg} / 100)$. Alcohol at levels of $250 \mathrm{mg} /$ $100 \mathrm{ml}$ (approximately $50 \mathrm{~mm}$ ) produced no alteration in the measured parameters of the perfused young guinea pig heart after $3 \mathrm{hr}$ of perfusion (Table I). With systolic pressure and ventricular perfusion load maintained at control levels, the amplitude, heart rate, and approximations of work (peak systolic pressure $X$ rate) (13), remained unchanged.

Incorporation of lysine $-{ }^{14} \mathrm{C}$ into total cardiac protein (Table II, columns A and B) at this level of ethanol was practically identical with the values found in control, and calculations of protein synthesis in right and left ventricles based on perfusate specific activities were unchanged. The protein nitrogen contents were also unchanged. The higher rate of protein synthesis within right ventricles as compared with the left has been reported previously in control perfusions (9).
Measurements of the intracellular nonprotein lysine $-{ }^{14} \mathrm{C}$ specific activity in the control left ventricles showed that the intracellular specific activity of the labeled lysine rose rapidly in the first $30-40 \mathrm{~min}$ and then very slowly thereafter (Fig. 2). Between 40 and 180 min there was only a slight increase in the specific activity from 0.6 to 0.7 that of the circulating perfusate. The inability of the intracellular lysine to fully equilibrate at $3 \mathrm{hr}$ has been reported previously in skeletal muscle and has been ascribed to nonradioactive lysine released by protein degradation freely mixing with the intracellular free lysine pool (14). Thus, the figures of protein synthesis reported in Table II (columns A and B) for the controls calculated from the perfusate specific activity were too small by a factor approximating $0.6-0.7$ (mean 0.65 ) and left ventricular protein synthesis more closely approximated $16.6 / 0.65$ or $25.6 \mu$ moles/g protein $\mathrm{N}$ after $3 \mathrm{hr}$ (Table II columns $\mathrm{C}$ and D).

Equilibration of the lysine ${ }^{-14} \mathrm{C}$ with the left ventricular nonprotein intracellular lysine pool with ethanol perfusion at $250 \mathrm{mg} / 100$ was identical with the controls (Fig. 2) and the mean value of left ventricular protein synthesis corrected for the intracellular specific activity was $24.3 \mu \mathrm{moles} / \mathrm{g}$ protein $\mathrm{N}$, essentially the same as that of controls (Table II columns C and D). There was also no significant difference in the intracellular pool size between controls and ethanol-perfused hearts (0.21 $\mu$ moles/g heart in each).

Equilibration of the lysine- ${ }^{14} \mathrm{C}$ intracellular pools was also measured separately in right ventricles and was 


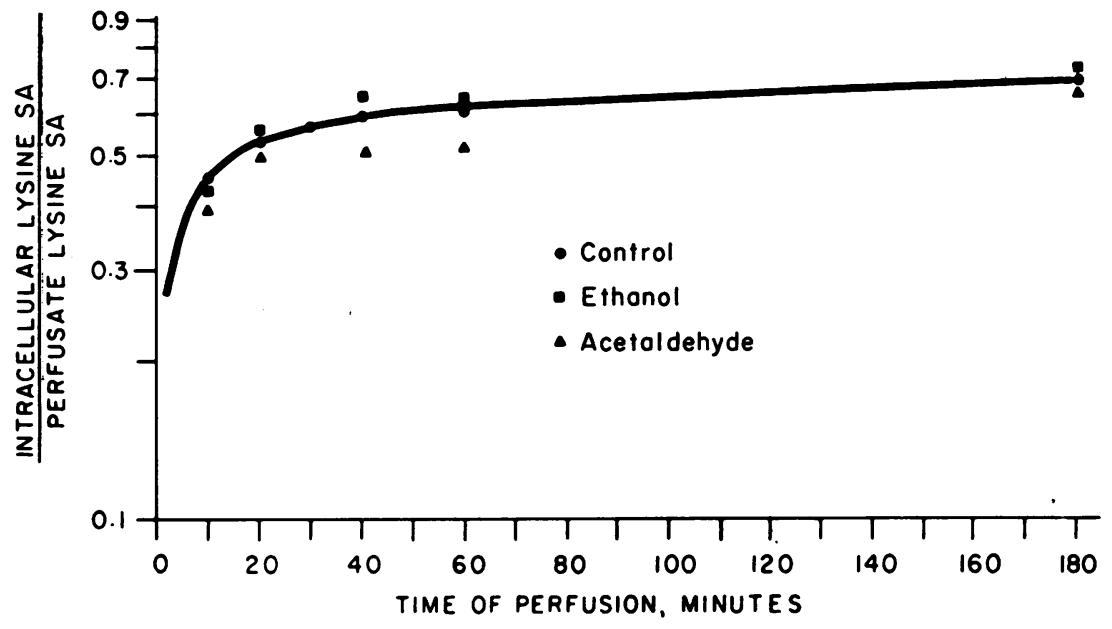

FIGURE 2 Measurement of the $1 y \operatorname{sine}-{ }^{14} \mathrm{C}$ equilibration of the left ventricular intracellular free lysine pool. For comparison, the specific activity of the lysine $-{ }^{14} \mathrm{C}$ is expressed as a fraction of the circulating perfusate specific activity. See Methods.

found to be identical with that of the left. Thus, the right ventricular nonprotein lysine- ${ }^{14} \mathrm{C}$ specific activity also rose to a level of 0.6 that of the perfusate by $40 \mathrm{~min}$ and did not exceed that of the left ventricle at $3 \mathrm{hr}$ (mean 0.7 of the perfusate specific activity). Similarly, equilibration of intracellular nonprotein lysine $-{ }^{14} \mathrm{C}$ in right ventricles was unchanged in ethanol, $(0.6-0.7$ that of the perfusate between $40-180 \mathrm{~min})$. Thus, right ventricular protein synthesis in control and ethanol-perfused hearts was $28.6 / 0.65$, or 44.1 and $22.7 / 0.65$, or $42.8 \mu \mathrm{moles} / \mathrm{g}$ protein $\mathrm{N}$, respectively (Table II columns $\mathrm{C}$ and $\mathrm{D}$ ). The difference is not significant.

Ethanol $(1300-1700 \mathrm{mg} / 100 \mathrm{ml})$. When ethanol was increased to levels far above those tolerated in the intact animal (mean $1500 \mathrm{mg} / 100 \mathrm{ml}$ with range 1300-1700 $\mathrm{mg} / 100 \mathrm{ml}$ during perfusion) some alterations were seen in the protein synthesis although the parameters of function were minimally altered (Table I). Although coronary flow appeared increased and cardiac rate and approximations of work slightly decreased, the changes were not statistically significant. The intracellular specific activity of the lysine- ${ }^{14} \mathrm{C}$ after $180 \mathrm{~min}$ of perfusion was not less than the control ( 0.7 that of the perfusate), but there was a decrease in incorporation of the lysine ${ }^{14} \mathrm{C}$ into ventricular protein in both right and left ventricles as well as a decreased protein nitrogen content of the right ventricle (Table II).

Acetaldehyde and incorporation of lysine- ${ }^{14} \mathrm{C}$ into myocardial protein. Since inhibitory effects on lysine- ${ }^{14} \mathrm{C}$ incorporation into protein were not seen at physiological levels of circulating ethanol, measurements of protein synthesis were made with a metabolite, acetaldehyde. The levels used produced an inotropic or chronotropic effect $(4,6,7)$, as well as an increased coronary perfu- sion (Table I). Despite the increased functional response, there was a marked decrease in incorporation of lysine $-{ }^{14} \mathrm{C}$ into cardiac protein of both right and left ventricles (Table II) when calculated from the lysine $-{ }^{14} \mathrm{C}$ specific activities in perfusate (Table II columns $\mathrm{A}$ and B). The protein $\mathrm{N}$ content was unchanged.

Acetaldehyde perfusion was associated with a slight decrease in equilibration of the intracelular-free lysine pool in both right and left ventricles compared with controls (Fig. 2). Thus, the lysine ${ }^{14} \mathrm{C}$ specific activity in the intracellular-free lysine pool was 0.51 of that in the perfusate at $60 \mathrm{~min}$ and 0.67 at $180 \mathrm{~min}$ compared with 0.60 and 0.71 in the controls during the same time peiods. Calculations of incorporation of lysine- ${ }^{14} \mathrm{C}$ into right and left ventricular protein based on the mean intracellular free lysine specific activity, between 40 and 180 min still showed a significant decrease from controls (Table II columns $\mathrm{C}$ and $\mathrm{D}$ ) indicating that the decreased incorporation was not due to the slight inhibition of entrance of the label into the intracellular free lysine pool. Thus, despite the presence of a marked inotropic effect, protein synthesis decreased. The inotropic and chronotropic effect, has been ascribed to released norepinephrine and can be abolished by propanalol $(4,6)$. With a concentration of propanalol of $2 \mathrm{mg} /$ liter sufficient to completely abolish the chronotropic effect, the incorporation of lysine- ${ }^{14} \mathrm{C}$ after $3 \mathrm{hr}$ was unchanged from the mean value obtained for acetaldehyde alone (Table II).

\section{DISCUSSION}

Although heavy alcohol intake is usually implicated in alcoholic neuropathy and hepatic disorders, the specific etiology of cardiomyopathy seen in alcoholism is not 
clear (1). Previous studies in our laboratory showed that acute exposure to levels of $200 \mathrm{mg} / 100 \mathrm{ml}$ of ethanol was sufficient to markedly depress hepatic albumin synthesis in the perfused liver (5), and thus, it was of interest to see if similar levels also depressed myocardial protein synthesis as a posible cause of cardiomyopathy. Perfusion with nonrecirculating ethanol levels of 250 $\mathrm{mg} / 100 \mathrm{ml}$ did not cause significant alterations in the perfused, working, guinea pig heart for $3 \mathrm{hr}$. Furthermore, the ability of the isolated heart to pump the left ventricular perfusion load was not altered in the face of maintained aortic systolic pressure. Recent evidence of in vivo studies in $\operatorname{dogs}(2,15)$ and man $(3,16)$ indicates that equivalent levels of alcohol may depress left ventricular function, particularly in previous cardiac disease $(3,16)$. Similarly, papillary muscles exposed to ethanol have shown a decreased contractile function (17). However, in dog heart preparations in situ, little contractile inhibition was seen by ethanol at $100 \mathrm{mg} / 100 \mathrm{ml}$ (18) and some decrease at $300 \mathrm{mg} / 100 \mathrm{ml}$. In other studies, no effect was seen until $1000 \mathrm{mg} / 100 \mathrm{ml}$, which is above the minimum lethal level (4), and no persistent effect on heart rate or work performance was seen in the rat and guinea pig until approximately $1000 \mathrm{mg} / 100 \mathrm{ml}$ $(6,7)$. In their review, Mitchell and Cohen have concluded that acute studies show little effect on cardiac performance (1). The present studies confirm the latter in the isolated perfused guinea pig heart since alterations in heart rate or visible work performance was not seen with acute exposure to ethanol at $250 \mathrm{mg} / 100 \mathrm{ml}$. It is recognized that direct measurements of time to develop peak left ventricular tension are indices of contractility which might show changes not evident in the parameters measured. However, since work and amplitude as measured here show a strong correlation to protein synthesis $(8,9,19)$, the present study employed the above model. Exposure to ethanol for $3 \mathrm{hr}$ also showed no effect on incorporation of lysine $-{ }^{14} \mathrm{C}$ into total cardiac protein or on the equilibration of the intracellularfree lysine pool. It is of interest that although alterations in triglyceride extraction and fatty acid distribution have been reported $(2,3,7)$, no significant decrease of ATP, ADP, creatine phosphate, or oxygen utilization have been seen $(7,15)$.

In the present study, it was not until levels lethal to the intact animal were used was there evidence of decreased lysine $-{ }^{14} \mathrm{C}$ incorporation into both right and left ventricular protein. At these lethal levels, ATP has been found to be significantly decreased (7) and the decreased protein synthesis may be related to the lower energy availability for such synthesis.

The inhibition of protein synthesis at the high ethanol levels may possibly be an osmotic effect. However, perfusion studies in this laboratory with albumin at levels of $1500 \mathrm{mg} / 100 \mathrm{ml}$, equivalent to $3.6 \mathrm{mOsm}$ at $\mathrm{pH} 7.4$, showed no difference in lysine $-{ }^{14} \mathrm{C}$ incorporation into protein from hearts perfused without albumin (unpublished data). Furthermore, with ethanol at $250 \mathrm{mg} /$ $100 \mathrm{ml}$ (approximately $54 \mathrm{mOsm}$ ), an increase in activity 15 times greater than albumin, assuming no major intracellular penetration, there was no change in protein synthesis or intracellular lysine equilibration from controls. If osmotic activity per se affected protein synthesis, an effect would be expected with this magnitude of change. However, a further increase of osmolarity of sixfold to $1500 \mathrm{mg} / 100 \mathrm{ml}$ ethanol may finally evoke an osmotic effect which cannot be excluded.

The present isolated heart perfusion model responded to acetaldehyde as has been previously described $(4,6)$ with a marked positive inotropic and chronotropic effect. The approximation of work (systolic pressure $X$ rate $X$ amplitude) with the same ventricular perfusion load was two times that of the control. Under such an increased work load, increased protein synthesis has been seen in control perfusion solutions (19). In the presence of acetaldehyde, there was instead a significant fall in the lysine $-{ }^{14} \mathrm{C}$ incorporated into protein. Although there may have been a slight decrease in equilibration of the intracellular free lysine pool (Fig. 2), calculations of protein synthesis based on the intracellular lysine $-{ }^{14} \mathrm{C}$ specific activity showed that acetaldehyde effected a significant decrease in protein synthesis of both ventricles despite the marked chronotropic and inotropic effect. The possibility that acetaldehyde may complex with lysine and produce an artifactual decrease in protein synthesis is not supported by the equilibration studies of the intracellular pool nor by calculations of protein synthesis based on the intracellular precursor pool mentioned above.

The stimulation of cardiac action by acetaldehyde is believed to be related to the release of catecholamines since the chronotropic action is blocked by propanolol $(4,6)$. The release of catecholamines was probably not the primary mechanism causing decreased protein synthesis since propanolol at levels sufficient to reduce the cardiac rate did not significantly change protein synthesis from that seen with acetaldehyde alone.

The mechanism by which acetaldehyde acts as a protein-synthetic inhibitor in the heart despite its marked stimulatory effect is unclear. Exploratory studies in this laboratory have not shown major disaggregation of polysomes by acetaldehyde, although alcohol which inhibits hepatic albumin synthesis disaggregates hepatic polysomes. Studies of energy metabolism so far reported, show no significant decrease in pyruvate or glucose metabolism $(7), \mathrm{O}_{2}$ consumption $(6,15)$, or palmitate- ${ }^{14} \mathrm{C}$ recovery as tissue lipids (7).

Although the levels of acetaldehyde used in the present perfusion studies with the guinea pig heart were higher

Ethanol, Acetaldehyde, Protein Synthesis 2825 
than those reported in human volunteers following ingestion of ethanol (20), it is of interest to speculate that the metabolite of ethanol, acetaldehyde, may play a role in the evolution of cardiac myopathy after prolonged exposure by interfering with normal myocardial protein synthesis.

\section{ACKNOWLEDGMENTS}

The authors gratefully acknowledge the technical assistance of Carol Evans, Fran Reff, and Hope Schreiber, the illustrations by Josephine Neglia, and the secretarial assistance of Mrs. Jean Miller.

This work was supported in part by grant HE 09562 from the National Heart Institute, and a grant from the Licensed Beverage Industries.

\section{REFERENCES}

1. Mitchell, J. H., and L. S. Cohen. 1970. Alcohol and the heart. Modern Concepts of Cardiovascular Disease. 39: 109.

2. Regan, T. J., G. Koroxenidis, C. B. Moschos, H. A. Oldewurtel, P. H. Lehan, and H. K. Hellems. 1966. The acute metabolic and hemodynamic responses of the left ventricle to ethanol. J. Clin. Invest. 45: 270.

3. Regan, T. J., G. E. Levinson, H. A. Oldewurtel, M. J. Frank, A. B. Weisse, and C. B. Moschos. 1969. Ventricular function in noncardiacs with alcoholic fatty liver: role of ethanol in the production of cardiomyopathy. J. Clin. Invest. 48: 397.

4. James, T. N., and E. S. Bear. 1967. Effects of ethanol and acetaldehyde on the heart. Am. Heart J. 74: 243.

5. Rothschild, M. A., M. Oratz. J. Mongelli, and S. S. Schreiber. 1971. Alcohol-induced depression of albumin synthesis: reversal by tryptophan. J. Clin. Invest. 50: 1812.

6. Gailis, L., and M. Verdy. 1971. The effect of ethanol and acetaldehyde on the metabolism and vascular resistance of the perfused heart. Can. J. Biochem. 49: 227.

7. Lochner, A., R. Cowley, and A. J. Brink. 1969. Effect of ethanol on metabolism and function of perfused rat heart. Am. Heart J. 78: 770.
8. Schreiber, S. S., M. Oratz, C. D. Evans, I. Gueyikian, and M. A. Rothschild. 1970. Myosin, myoglobin and collagen synthesis in acute cardiac overload. $\mathrm{Am}$. J. Physiol. 219: 481.

9. Schreiber, S. S., M. Oratz, and M. A. Rothschild. 1966. Protein synthesis in the overloaded mammalian heart. Am. J. Physiol. 211 : 314.

10. Bergmeyer, H. U. 1965. Methods of Enzymatic Analysis. Academic Press, Inc., New York. 290.

11. Morgan, H. E., D. C. N. Earl, A. Broadus, E. B. Wolpert, K. E. Giger, and L. S. Jefferson. 1971. Regulation of protein synthesis in heart muscle. I. Effect of amino acid levels on protein synthesis. J. Biol. Chem. 246: 2152.

12. Schreiber, S. S., M. Oratz, and M. A. Rothschild. 1964. Ion diffusion delay in the beating mammalian heart. Proc. Soc. Exp. Biol. Med. 116: 164.

13. Opie, L. H. 1965. Coronary flow rate and perfusion pressure as determinants of mechanical function and oxidative metabolism of the isolated perfused rat heart. $J$. Physiol. (Lond.). 180: 529.

14. Gan, J. C., and H. Jeffay. 1967. Origins and metabolism of the intracellular amino acid pools in rat liver and muscle. Biochim. Biophys. Acta. 148: 448.

15. Ganz, V. 1963. The acute effect of alcohol on the circulation and on the oxygen metabolism of the heart. $\mathrm{Am}$. Heart J. 66: 494.

16. Gould, L., M. Zahir, A. DeMartino, and R. F. Gomprecht. 1971. Cardiac effects of a cocktail. J. Am. Med. Assoc. 218 : 1799.

17. Spann, J. F., D. T. Mason, G. D. Beiser, and H. K. Gold. 1968. Actions of ethanol on the contractile state of the normal and failing cat papillary muscle. Clin. Res. 16 : 249. (Abstr.)

18. Mierzwiak, D. S., K. Wildenthal, and J. H. Mitchell. 1967. Effect of ethanol on the canine left ventricle. Clin. Res. 15: 215. (Abstr.)

19. Schreiber, S. S., M. Oratz, and M. A. Rothschild. 1971. Initiation of protein synthesis in the acutely overloaded perfused heart. In Cardiac Hypertrophy. N. R. Alpert, editor. Academic Press, Inc., New York. 1st edition. 215.

20. Majchrowicz, E., and J. H. Mendelson. 1970. Blood concentrations of acetaldehyde and ethanol in chronic alcoholics. Science (Wash. D. C.). 168: 1100. 